\title{
Investigations of the guided wave data analysis capabilities in structural health monitoring of composite objects
}

\author{
L.Mažeika $^{1}$, V.Samaitis ${ }^{1}$, K.Burnham ${ }^{2}$, K.Makaya ${ }^{2}$ \\ ${ }^{1}$ - Kaunas University of Technology, Studentu 50, LT-51368, Kaunas, Lithuania \\ 2 - TWI Ltd, Granta Park, Great Abington, Cambridge CB21 6AL, United Kingdom
}

\begin{abstract}
Ultrasonic guided waves are widely used for non-destructive testing of composite objects. Low frequency guided waves propagate long distances, so they can be used in structural health monitoring systems. However, in order to increase efficiency of guided waves usage in structural health monitoring systems, deep analysis of the measured signals is required. Usually non-destructive testing systems exploit the signals measured different positions of the object under investigation. In structural health monitoring systems the amount of measurement positions is limited and analysis of guided wave signals is more complicated.

The objective of this work was to investigate which guided wave parameters can be measured and monitored during the bending tests of composite plates. The analysis of the experimental signals showed that using embedded transducers it is possible to measure group velocity of the fastest wave, directivity pattern of ultrasonic transducers and even to estimate the anisotropy of group velocity. The investigation also revealed that identification of other guided wave modes requires a numerical model which simulates the wave propagation in the object under investigation. Detailed analysis of experimental signals showed that precise measurements of delay times and amplitudes enable to estimate relatively small changes of the object properties.
\end{abstract}

Keywords: Structural Health Monitoring, ultrasonic guided waves, composite structures.

\section{Introduction}

Structural health monitoring (SHM) systems are one of the most promising damage detection and characterization strategies for engineering components. It helps to improve the safety, reliability and durability of various critical structures, by combining an array of embedded transducers for capturing data during the measurements. There are five most common techniques used for implementation of SHM systems [1-5]. One of the most promising of them is based on excitation and reception of ultrasonic guided waves $(\mathrm{GW})$ and measurement of their parameters.

However the implementation of SHM systems, based on guided waves, faces a lot of problems which are related to complicated analysis of the signals captured from the object under investigation. Such analysis is complicated due to multiple reflections and mode conversion of ultrasonic guided waves. Also, the wave parameters are related to the environmental conditions of the object under investigation. In order to increase the efficiency of a guided wave usage in SHM systems, deep analysis of measured signals is required.

The purpose of this work was to carry out the load test on the composite object sample, to investigate how a load affects the guided wave propagation and to determine if the arising defect could be detected during the load variations.

\section{Set-up of the experiments}

The load test has been carried out on the $7.4 \mathrm{~mm}$ thickness, 16-ply $\left[0^{\circ} / 90^{\circ}\right]$ GFRP plate. The dimensions of the plate are $1300 \mathrm{~mm} \times 1000 \mathrm{~mm}$. The load bending the surface of the object under investigation was used. For excitation and reception of guided wave signals the MFC transducers (micro fiber composite) were used. The dimensions of the transducer are $28 \times 14 \mathrm{~mm}$. The transducers were attached to the plate using two side sticky tape. Totally 12 MFC transducers were used. For data acquisition the Teletest system was used. The general view of the GFRP plate with attached transducers is presented in Fig. 1.

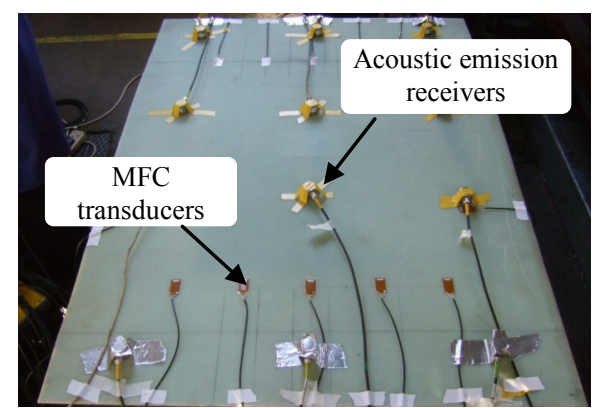

Fig. 1. The general view of the GFRP plate prepared for the experiments

The investigation was performed by following order: during the measurements only one of the transducers was activated (transmitter) and the signals of all the rest MFC receivers (totally 12) were recorded. The transducers were excited using a single pulse corresponding to $45 \mathrm{kHz}$ frequency. As transmitters, the 6 transducers with numbers 1,3,4,5,9,10 were used (Fig. 2.).

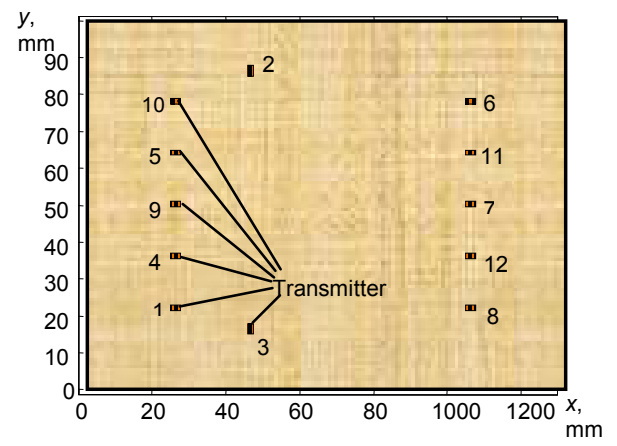

Fig. 2. The schematic view of the positions of attached MFC transducers 
Table 1. The positions of MFC transducers on the GFRP plate

\begin{tabular}{|c|c|c|c|}
\hline $\begin{array}{c}\text { Transducers } \\
\text { numbers }\end{array}$ & $\begin{array}{c}\text { Excitation } \\
\text { order }\end{array}$ & $x_{t r}, \mathrm{~mm}$ & $y_{t r}, \mathrm{~mm}$ \\
\hline 1 & 1 & 250 & 215 \\
\hline 2 & - & 460 & 850 \\
\hline 3 & 6 & 460 & 150 \\
\hline 4 & 2 & 250 & 355 \\
\hline 5 & 4 & 250 & 635 \\
\hline 6 & - & 1050 & 775 \\
\hline 7 & - & 1050 & 495 \\
\hline 8 & - & 1050 & 215 \\
\hline 9 & 3 & 250 & 495 \\
\hline 10 & 5 & 250 & 775 \\
\hline 11 & - & 1050 & 635 \\
\hline 12 & - & 1050 & 355 \\
\hline
\end{tabular}

So, at each load condition totally $12 * 6=72$ signals were recorded. The accurate positions of $\mathrm{GW}$ transducers and excitation order of the MFC transmitters is presented in Table 1. The time diagram of the load experiment is presented in Fig. 3. After one hour from the experiment start there was time brake during which the load was taken out. By red dots the time instants at which the guided wave signals were measured are denoted. Totally, there were 12 guided wave measurement sessions. The deformation of the GFRP plate under the biggest load $(6500 \mathrm{~N})$ can be seen in Fig. 4.

Applied Force $(\mathrm{N})$

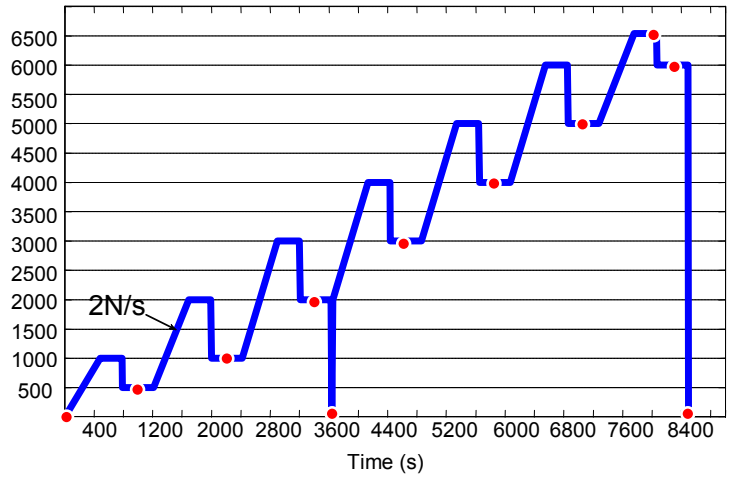

Fig. 3. The time diagram of bending experiments (the dots shows when the guided waves signals were measured)

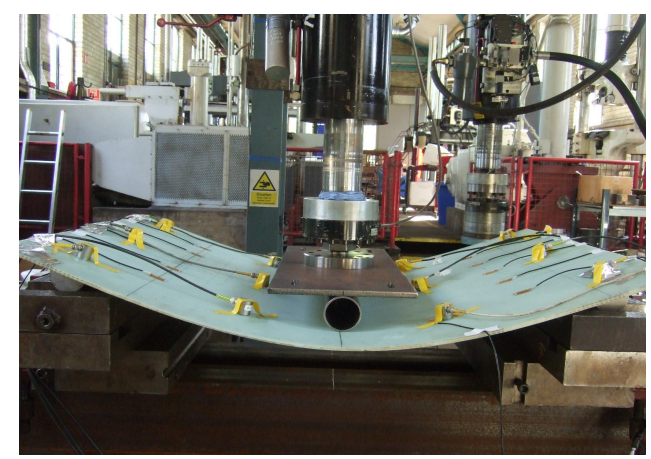

Fig. 4. The deformation of the GFRP plate under $6500 \mathrm{~N}$ load

\section{Analysis of the waveforms of the signals}

The example of the waveform of the measured GW signal is presented in Fig. 5. The signal was measured between the $9^{\text {th }}$ and the $7^{\text {th }}$ transducers $\left(9^{\text {th }}\right.$ was the transmitter, $7^{\text {th }}$ was the receiver) in the case of different loads.
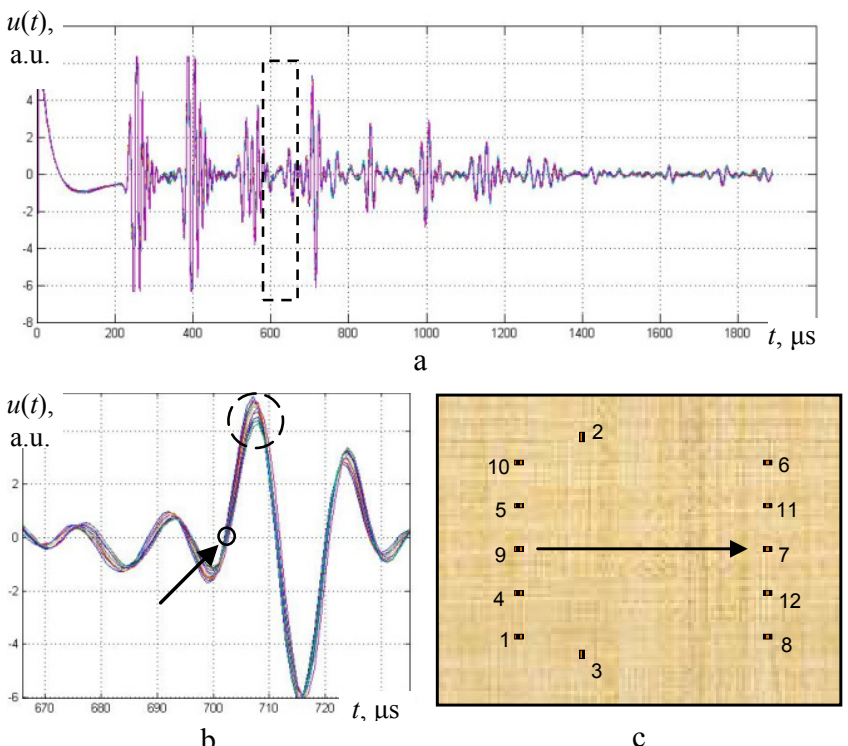

Fig. 5. The waveform of the signals (a) measured between $9^{\text {th }}$ and $7^{\text {th }}$ transducers (c) and the zoomed part of it (b) in the case of a different load

As can be seen from the figure, the signals measured at different loads almost overlap on each over. However some changes of the parameters in the zoomed signal can be observed (Fig. 6b). It can be seen that there are some variations of the amplitude and delay time of different segments of the signal. The signals measured between other two transducers $\left(9^{\text {th }}\right.$ is the transmitter and $8^{\text {th }}$ is the receiver) are presented in Fig. 6.
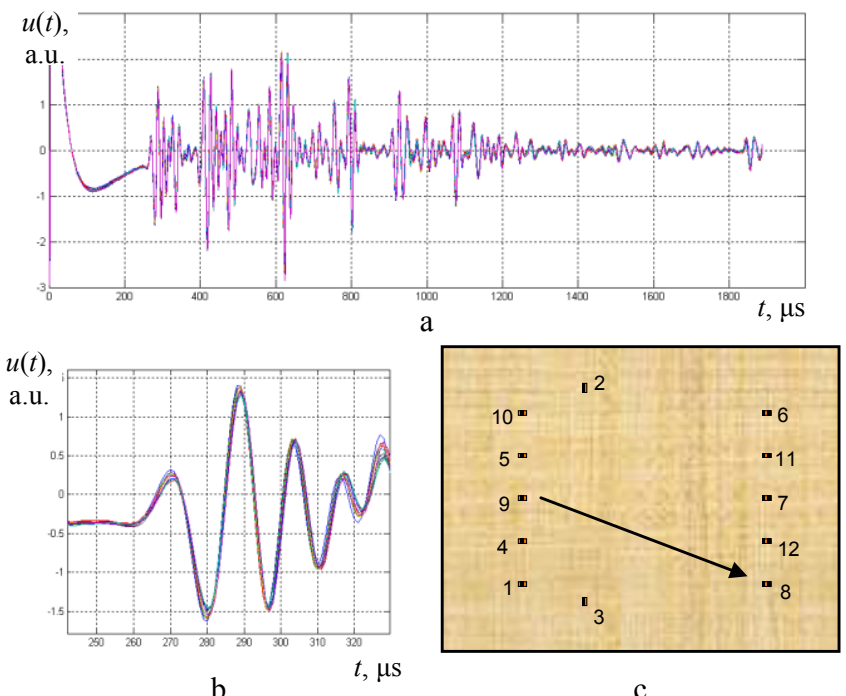

Fig. 6. The waveform of the signals (a) measured between $9^{\text {th }}$ and $8^{\text {th }}$ transducers (c) and the zoomed part of it (b) in the case of a different load

The signals possess a different waveform, however they demonstrate similar general regularities (Fig.6b) 
related to the load, where the variations of the amplitude and the delay time can be observed also. Identification of different propagating modes in the recorded signal is complicated task. Reliably only the fastest $\mathrm{S}_{0}$ mode of Lamb waves with the group velocity about $3400-3500 \mathrm{~m} / \mathrm{s}$ can be identified. In order to determine the velocity more accurately the detailed analysis is needed. Identification of other modes is more complicated because the signals of these modes are mixed with different reflections of the $\mathrm{S}_{0}$ mode.

However the main objectives of the analysis of load experiments is not to identify modes, but to determine if some changes of the signal parameters related to the load exist. In order to determine this relation the variations of the amplitude and the delay time were analyzed more detailed.

\section{Analysis of the amplitudes of the signals}

The measurement of amplitudes of the signals can be assumed to be the easy task. However the key question is: the amplitude of what should be measured? In the signal the different modes and different multiple reflections are present. On the other hand the amplitude not only of the signal itself but also the amplitude of the background noise (the signals between strong reflection) can be measured. Increase of the amplitude of a background noise can be related to appearance of new wave modes caused by the mode reflection on the arising defect. There are not so many investigations which determine the criteria for selection of the most important parts of the signal for analysis. In the preliminary analysis it was decided just to select one of the reflections and to monitor variations of the amplitude in relation to the load. The signal selected for the amplitude analysis is denoted in Fig.5b by a circle. The maximal amplitude was estimated in the time interval $[700 ; 715] \mu$ s. The obtained results are presented in Fig.7

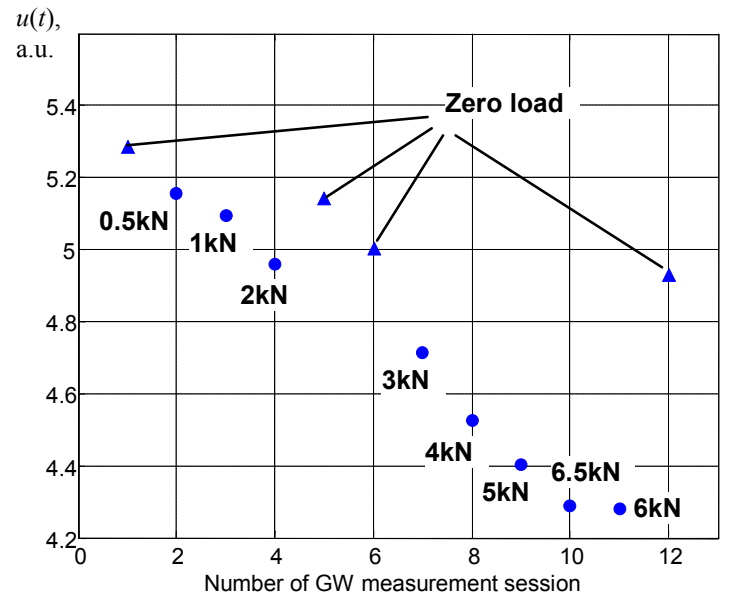

Fig. 7. The amplitude of the half period in the time interval ranges $[700 ; 715] \mu$ s of the signal measured between the $9^{\text {th }}$ and the $7^{\text {th }}$ transducers at different loads

As can be seen there is a trend of the signal amplitude depending on the load. However there is some trend of the amplitudes measured at zero loads also. It can be not stated that there are some residual changes in the composite which does not disappear after the load is taken off. The small trend can be caused by other phenomena such as changes of temperature, coupling characteristics, slow variations of parameters of the electronic unit and etc. The analysis of amplitudes of another half periods demonstrates that their behavior can be different (Fig.8).

Some of them possess the analyzed regularity (Fig.8a) and some of them do not depend on the load (Fig.8b) even in the signal measured between the same transducers. Probably it can be explained that they correspond to different guided wave modes.
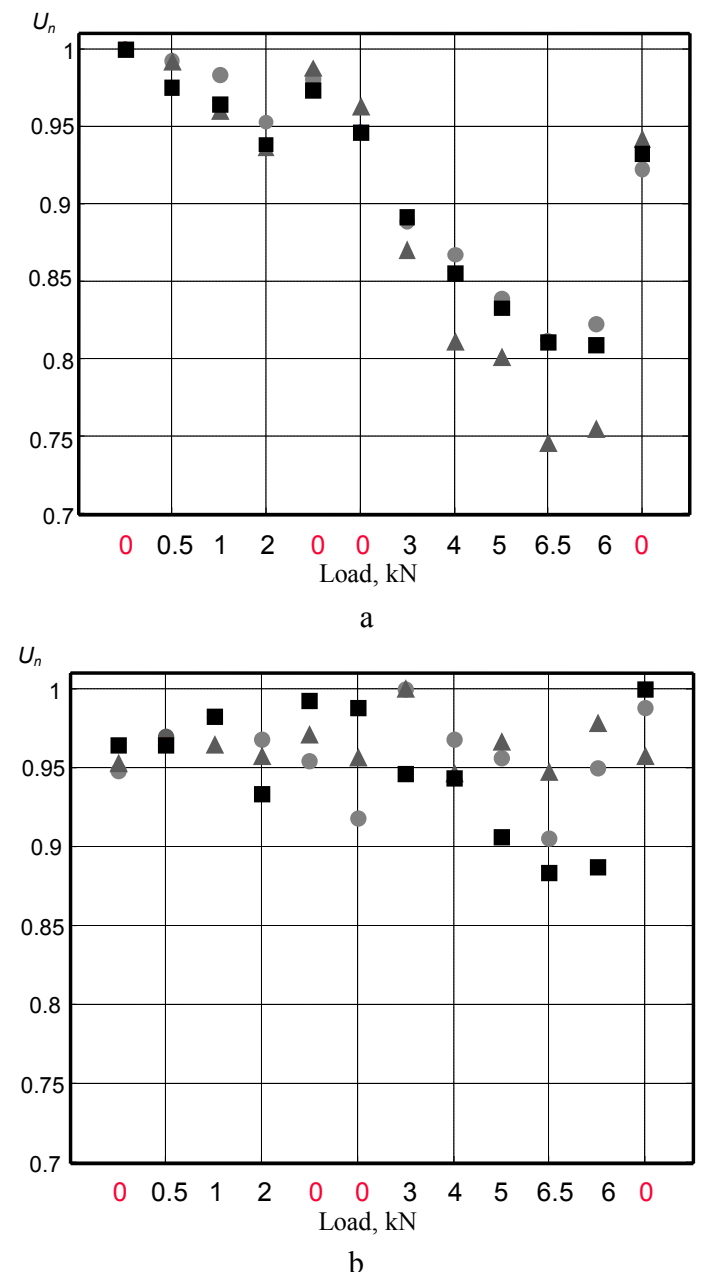

Fig. 8. The amplitude of the half period of the signal measured between the $9^{\text {th }}$ and the $7^{\text {th }}$ transducers at different loads. The time intervals: a - circles [235-245] $\mu$ s; triangles [375-383] $\mu$ s; square $[700 ; 715] \mu s ; b$ - circles $[535-540] \mu s$; triangles $[565-570] \mu s$; square $[850-860] \mu s$

The measurement of the amplitude of small signals or background noise gives different regularities (Fig.9). In some cases the strong increase of the amplitude at a high load can be observed, which reduces when the load is taken of. Of course such analysis is time consuming, subjective and non-automated. However it enables to make some conclusions:

- Measurement of the amplitude of the guided wave signal corresponding to different time intervals enables to observe regularities related to the values of the load. However, these dependencies are not strongly expressed at least in the load ranges which were used in the experiments; 
- The analysis did not reveal the changes of the signal which can be related to the development of the defects or presents of damages related to the load experiments;

- The observed regularities of amplitude variations are relatively small and dependent on the time interval in the signal. So, for a reliable nondestructive testing (monitoring) the necessary signal processing algorithms should be developed. $U_{n}$

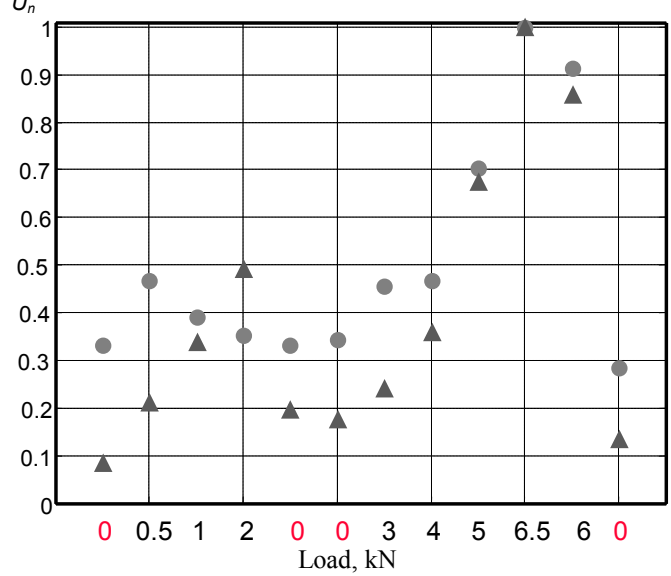

Fig. 9. The amplitude of the half period of the signal measured between the $9^{\text {th }}$ and the $7^{\text {th }}$ transducers at different loads. The time ranges: circle $-[1480-1500] \mu \mathrm{s}$; triangle $-[895-905] \mu \mathrm{s}$.

\section{Analysis of the delay time of the signals}

In general the measurements based on the delay time estimation are more accurate comparing to the ones based on the amplitude evaluation. However at first it should be defined what delay time of what and using what technique should be measured.

In the case of guided waves a delay time related to the phase and group velocities can be discussed. The group velocity defines usually a general delay of the burst of the signal which is usually measured using envelope of the signal. The phase velocity is related to the shift of the phase of the signal and cannot be estimated using a single signal. However the objective of this analysis is not to measure the phase velocity, but just to detect possible changes of the phase velocity. In general the phase velocity can be estimated by measurements of the zero-crossing instants in the signal [6-7].

The signals presented in Fig.5b were analyzed using zero-crossing techniques. The zero-crossing instant marked by the arrow in Fig. 5 was measured and analyzed. This time instant was measured in the case of each load. The obtained results are presented in Fig.11, in the form of deviation of the zero-crossing instant with respect to the mean value:

$$
\delta t_{k}=t_{k}-\frac{1}{N_{L}} \sum_{k=1}^{N_{L}} t_{k}
$$

where $t_{k}$ are the measured time instancts of the zerocrossing point at different loads, $N_{L}=12$ is the number of the loads used in the experiment (or number of GW measurement sessions).
A clearly expressed trend can be observed in the presented results. However it seems that it is not dependent on the load but just on time, because the results corresponding to the zero load also fit well into the trend does not depending when the measurements at zero load were performed at the very beginning of the experiment, in the middle of it or at the end. This is a very small variation of the delay time, less than $1 \mu \mathrm{s}$. The similar trend can be observed in the case of other zero-crossing points in different parts of the signal also (Fig.11).

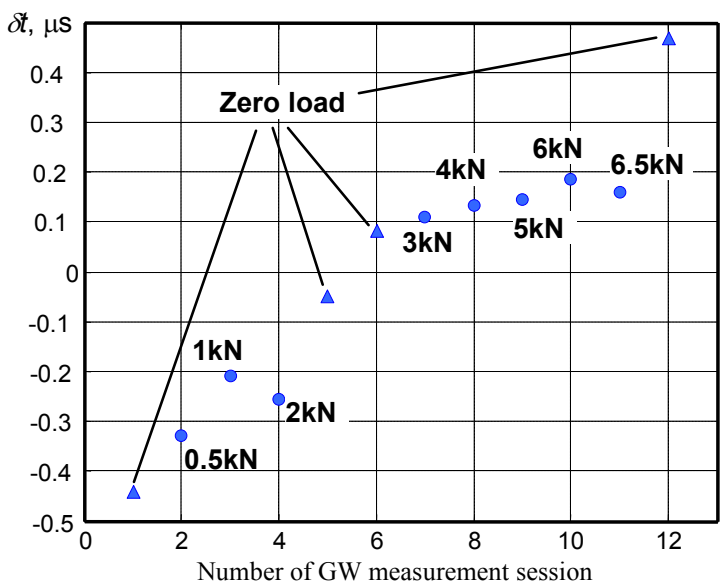

Fig. 10. The variations of the time instant of one the zero-crossing points (marked in Fig.6b) of the signal measured between the $9^{\text {th }}$ and the $7^{\text {th }}$ transducers at different loads
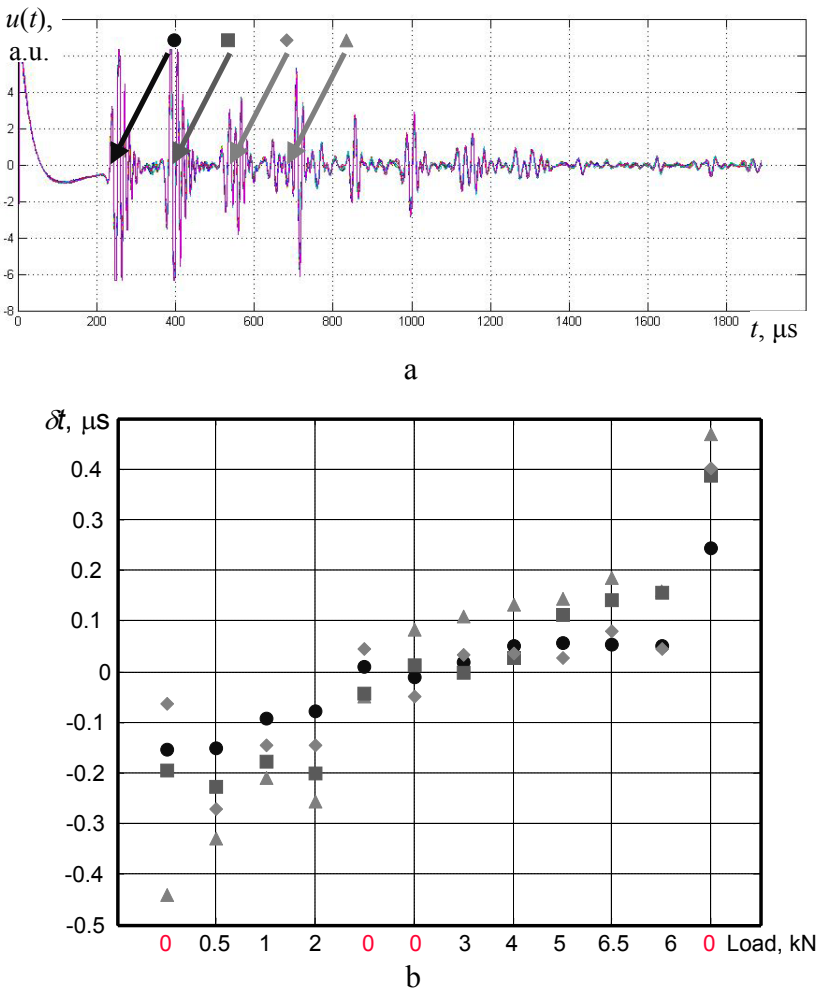

Fig. 11. The signal measured between the $9^{\text {th }}$ and the $7^{\text {th }}$ transducers (a) and the variation of the time instant of the different zerocrossing points (b)

The trends of different zero-crossing points are slightly different however demonstrates the same character. A more detailed analysis shows that the steepness of this trend 
slightly increases for the later interval of the signal. There is no clear explanation of this regularity. May be it is caused by a small increase of the temperature in the experiment site during the day. Any changes of the temperature should lead to small variations of the propagation velocity of guided waves and as a consequence to some additional delays of signals. Several conclusions follow from the investigation of delay times:

- The measured variations of the delay time of different reflections in the signal are relatively small and does not reveal any regularities related to the load;

- The accurate measurements of the delay time demonstrated that this is very sensitive technique and very different phenomena affecting the composite under investigation can be detected. However, the origin of determined regularities was not identified, there is only assumption that it can be influenced by temperature variations.

\section{Identification of modes and reflections}

The regularities analyzed in the previous chapters were not related to the Lamb wave modes or reflections. Such approach have some advantage in the case of monitoring because does not require a deep analysis of the signal including mode identification. On the other hand, much information which is contained in the signals is still not exploited. In this chapter the results of more detailed analysis of the signals are presented.

At first the parameters of generated waves can be verified. A simpler analysis is of the $\mathrm{S}_{0}$ mode which arrives first. The directivity of the generated $S_{0}$ mode can be obtained using the signals generated by the transducers 1 and 3 and received by the transducers $6,11,7,12$ and 8 (Fig.12a). The directivity pattern of the MFC transducers in the case of the $\mathrm{S}_{0}$ mode and obtained from the experiment data is presented in Fig.12b. The directivity patterns were estimated according to:

$$
D_{S_{0}}\left(\alpha_{k}\right)=\sqrt{U\left(\alpha_{k}\right) / \max \left[U\left(\alpha_{k}\right)\right]}
$$

where $U\left(\alpha_{k}\right)=\max _{t}[u(t)]-\min _{t} x[u(t)], \quad t \in\left[t_{1, S 0}, t_{2, S 0}\right]$; $\left[t_{1, S 0}, t_{2, S 0}\right]$ is the time interval in the signal corresponding to the direct $\mathrm{S}_{0}$ mode; $\alpha_{k}=\arctan \left[\left(y_{k, R c}-y_{k, T r}\right) /\left(x_{k, R c}-x_{k, T r}\right)\right]$ is the angle of the receiver with respect to the transmitter; $\left(x_{k, T r}, y_{k, T r}\right)$ and $\left(x_{k, R c}, y_{k, R c}\right)$ are positions of the transmitter and receiver on the GFRP plate; $k=1 \div 12$ is the number of transducer pairs used for the directivity pattern estimation.

The directivity pattern was measured only in one quarter and in other quarters were drawn only according to the assumption that directivity of the transducers should be symmetric with respect to both axes.

Using the same signals the group velocity of the $S_{0}$ mode can be estimated. It was measured using the signals between the transmitter 1 and the receivers 6,11,7,12,8. Additionally the group velocity was measured across the GFRP plate using transducers 3 and 2. As the result the group velocities were measured along different direction on the GFRP plate. Taking into account the expected symmetry the dependency of the group velocity versus angle was obtained (Fig.13).

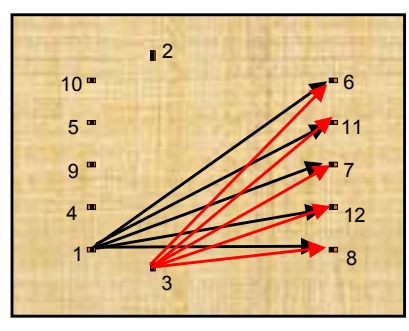

a

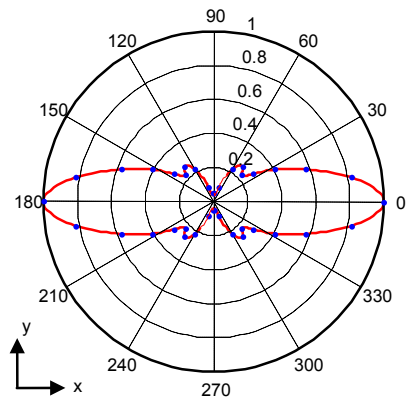

b
Fig. 12. The directivity patterns of the MFC transducers in the case of $S_{0}$ mode (b) and used pairs of transducers (a)

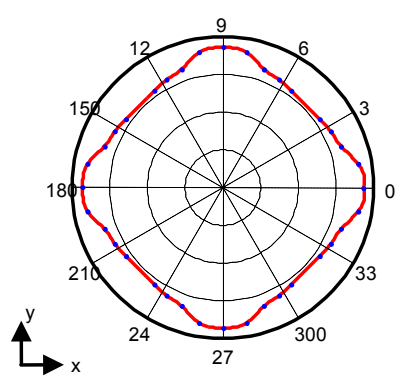

Fig. 13. The group velocities of the $S_{0}$ mode in the GFRP plate versus angle obtained using the bending experiment data

The presented results demonstrate anisotropy of the group velocity of $\mathrm{S}_{0}$ mode where the maximal velocity is along the $x$ and $y$ axis and is equal approximately to $3700 \mathrm{~m} / \mathrm{s}$. The directions of the slowest group velocity correspond to the angles $45^{\circ}, 135^{\circ}, 225^{\circ}, 315^{\circ}$. In these directions the group velocity approximately is equal to $3150 \mathrm{~m} / \mathrm{s}$.

The identification of different modes and reflections in the signals is ambiguous task. However using the model developed in Ultrasound Institute [8] it is possible partially to solve it. The identified modes and reflections are shown in Fig.14 and Fig. 15.

Most of reflections correspond to the propagating $\mathrm{S}_{0}$ mode. The reflections of other modes overlaps with different reflections of $\mathrm{S}_{0}$ and cannot be observed in the signal as a separate reflection. For example, the direct signal of the $\mathrm{A}_{0}$ mode coincides with the 3 reflection of the $\mathrm{S}_{0}$ wave.

\section{Conclusions}

The accurate measurement of the parameters of recorded signals demonstrated that more sensible to the load are the amplitudes of the signals, which are correlated to it. The measured delay time of the signal does not reveal correlation to the load; however it was shown that it can be very sensitive to other phenomena influencing composite. 
$u(t)$

a.u.

$u(t)$

a.u.

$u(t)$

a.u.
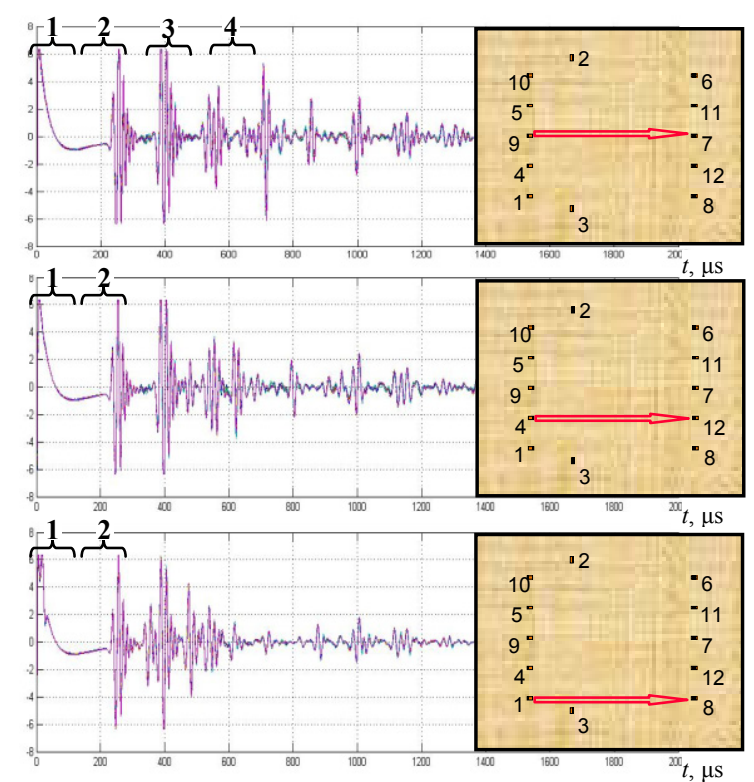

Fig. 14. The signals analyzed for mode and reflections identification
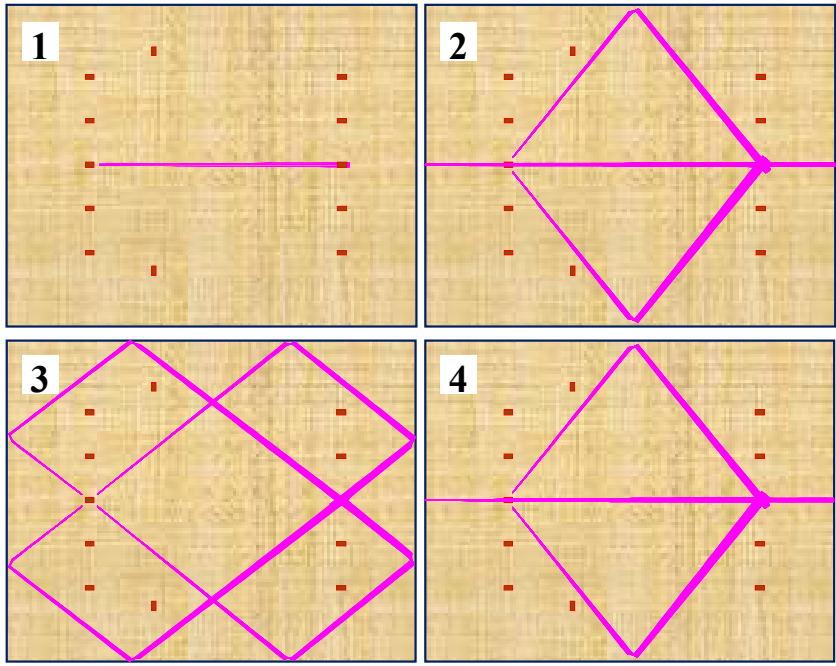

Fig. 15. Explanation of some reflections: 1-3 correspond to $S_{\mathbf{0}}$ mode; 4 - the same paths as $3^{\text {rd }}$ just for $A_{0}$ mode.

The experiments carried out did not reveal any regularity which can be related to the defect development during the load.

As the result of a more detailed analysis, the directivity of the MFC transducer generating the $\mathrm{S}_{0}$ mode in GFRP plate and anisotropy of the group velocity of the $\mathrm{S}_{0}$ mode were determined and demonstrated. Also a part of the propagating modes and reflections in the recorded signals were identified.

\section{Acknowledgements}

The part of this work was sponsored by the European Union under the Framework-7 project COMPAIR
"Continuous health monitoring and non-destructive assessment of composites and composite repairs on surface transport applications".

\section{References}

1. Giurgiutiu V., Zagrai A. Damage Detection in Thin Plates and Aerospace Structures with Electro-Mechanical Impedance Method. Structural Health Monitoring. 2005. Vol. 2. No. 4. P. 99-118.

2. Zagrai A., Cakan N. Magneto-Mechanical Impedance Identification and Diagnosis of Metallic Structures. International Journal of Engineering Science. 2010. Vol. 10. No. 48. P. 888-908.

3. Katsikeros Ch., Labeas G. N. Development and Validation of Strain-Based Structural Health Monitoring System. Mechanical Systems and Signal Processing. 2009. Vol. 2. No. 23. P. 372-383.

4. Nair A., Cai C. S. Acoustic Emission Monitoring of Bridges: Review and Case Studies. Engineering Structures. 2010. Vol. 6. No. 32. P. 1704-1714.

5. Raghavan A., Cesnik C. E. S. Review of Guided-Wave Structural Health Monitoring. The Shock and Vibration Digest. 2008. Vol. 91. No. 39.

6. Mažeika L., Draudvilienè L. Analysis of the zero-crossing technique in relation to measurements of phase velocities of the Lamb waves. Ultrasound. 2010. Vol.66. No.2. P.7-12.

7. Mažeika L., Draudvilienė L., Žukauskas E. Influence of dispersion on measurement of phase and group velocities of Lamb waves. Ultrasound. 2009. Vol.64. No.4. P.18-21.

8. Kažys R., Mažeika L., Samaitis V. Analysis of ultrasonic guided wave signals in structural health monitoring of composite objects. Proceedings of the $50^{\text {th }}$ annual conference of the British Institute of Non-Destructive Testing, September 13-15, 2011. Telford. UK.

L.Mažeika, V.Samaitis, K.Burnham, K.Makaya

Stebėsenos, atliekamos naudojant nukreiptąsias ultragarso bangas, duomenų analizès galimybių tyrimas

Reziumé

Nukreiptosios ultragarso bangos plačiai naudojamos kompozitu neardomiesiems bandymams atlikti. Dèl savybès sklisti didelius atstumus jos labai tinka saugios objektų eksploatacijos stebėsenos sistemoms, tačiau, kad būtų efektyviai naudojamos, reikia atlikti detalią matuojamų signalu analizę. Neardomuju bandymu atveju ši uždavini iš dalies palengvina didelis kiekis signalų, skenavimo metu išmatuotų daugelyje tiriamo objekto taškų. Šių signalų analize igalina identifikuoti ịvairias sklindančias nukreiptųų bangų modas ir jų parametrus. Stebėsenos sistemoms keitiklių ar matavimo taškų reikia kur kas mažiau.

Darbo tikslas buvo naudojantis eksperimentiniais duomenimis, gautais lenkimo bandymų stebėsenos metu, ištirti, kokie nukreiptụjų bangų parametrai gali būti išmatuoti ir kokie - stebimi apkrovos sąlygų kitimo metu. Tyrimai parodè, kad esant ribotam keitiklių skaičiui ir palyginti paprastam ju išdèstymui, vis tiek galima išmatuoti bent jau greičiausiai sklindančios bangos grupinius greičius, netgi nustatyti jų anizotropiją. Be to, galima gana tiksliai nustatyti keitiklių kryptingumo diagramą. Reikia atsižvelgti ị tai, kad šis parametras nukreiptųjų bangų atveju sąlygotas ne tik keitiklio, bet ir objekto. Iš tyrimo rezultatų matyti, kad kitas modas identifikuoti signale galima tik naudojant skaitmeninius modelius, imituojančius jų sklidimą objekte. Detali signalų analizė parodè, kad tiksliai išmatavus pavieniu atspindžiu signale suvėlinimo laiką ir amplitudę, išryškèja palyginti maži objekto parametrų pokyčiai.

Pateikta spaudai 20110926 